\title{
EXPERIMENTAL OPTIMIZATION OF AN ANISOTROPIC ETCHING PROCESS FOR RANDOM TEXTURIZATION OF SILICON SOLAR CELLS
}

\author{
Devid L. King and M. Elaine Buck \\ Sandia National Leboratories
}

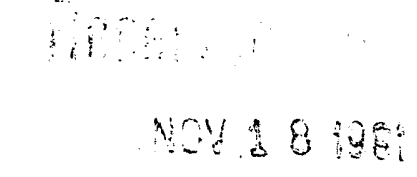

\section{ABSTRACT}

A multifactor experimental investigation of silicon surface texturing was conducted in Sandia's Photovoltaic Device Fabrication Laboratory using aqueous potassium-hydroxide (KOH) solutions with isopropyl alcohol (IPA) added as a complexing agent. Czochralski, magnetic-Czochralski, and float-zone silicon wafers of different resistivities with both polished and lapped surfaces were included in the experiment. Process variables considered were solution temperature, time in solution, degree of mechantcal mixing, $\mathrm{KOH}$ concentration, arid IPA concentration. Using hemispherical reflectance as the primary gauge of success, process variables were identifled that resulted in an ffective surface texture with reflectance less than 12 prior to anti-reflection coating. of particular interest was a low temperature $\left(70^{\circ} \mathrm{C}\right)$ process with less than 2 concentration of both $\mathrm{KOH}$ and IPA and wide process variable tolerances.

\section{INTRODUCTION}

Anisotropic etching using concentrated alkaline solutions at elevated temperatures is often done in the semiconductor Industry to thin or pattern single-crystal silicon wafers. These etching processes have been thoroughly characterized for silicon wafers of different crystalline orientations and different doping densities $[1,2]$.

Relatively mild alkaline solutions with low concentrations (less than 5t) of eithe: potassium hydroxide (KOH) or sodium hydroxide (NaCh) are also used to etch a textured surface of microscopic pyramids on silicon wafers with $\langle 100\rangle$-oriented surfaces. For solar cells, this textured surface is used to inimize reflection losses from the front surface and to enhance optical light-trapping within silicon cells that have a reflective back surface [3].

This work supported by the Photovoltalc Energy Technology Division, U.S. Department of Energy, contract DE-AC04-76DP00789.
Unfortunately, the chemical processes used for surface texturing of 811 icon are not as well surface texturing of silicon are those used for thinning and etching in the semiconductor industry. Research laboratories and many industrial firms that use surface texturing processes typically haven't had the opportunity to optimize the process for optical effectiveness, cost, and safety $[4,5]$.

The Photovoltalc Device Fabrication Laboratory (PDFL) is actively involved ... collaborative research with the U.S. photovoitaic industry to identify optimized silicon prccessing procedures that increase the efficlency and lower the cost of silicon solar cells. In order to implement a wellcharacterized surface texturing process in the PDFL, we conducted a multifactor experimental investigation of silicon texturing using aqueous $\mathrm{KOH}$ solutions. Our objective was to Identify a process that provides repeatable and uniform surface texture with low chemical usage, low chemical disposal costs, and with minimal vapor effluent.

\section{EXPERIMENT DESIGN}

An experimental strategy based on response surface methodology was used to iesign an 18 -trial surface texturing experinent using aqueous KOH solutions with 1sopropyl alcohol (IPA) added as a couplexing agent. The details of the chemical reactions that occur during the etching process were not investigated, but other work has indicated that the addition of the IPA facilitates the texture etching process by dissolving hydrous silica formed at the reaction interface [2]. Czochralski (Cz), magnet1:-Czochralski ( $M C z$ ), and float-zone (FZ) silicon wafers of different resistivities and with both polished and lapped surfaces were included in the experiment. Table 1 describes the types of wafers used in the experiment. Two wafers of each type were included in each trial of the experiment.

The five process variables (factors) evaluated were solution temperature, time in solution, degree of mechanical agltation, KOH concentration, and IPA concentration. Table 2 gives the ranges considered for each process variable. The ranges chosen were believed to include most conditions evaluated by other researchers. With the exception of three 
trials run at ald-range for all variables, all trlals were run using combinations of the extrenes of the ranges given in Table 2 .

The responses masured during this experinent vere the hemispherical spectrul reflectance of the textured surface, pyramid-base vidth, texture uniformity, and etch rate. Measured results vere analyzed using a program called STRATEGY designed for statietically analyzing the results of aultifactor experinents $[6\}$.

Subsequent to this initial 18-triel experibent, several additionel trials have been conducted in the PDFL that helped refine the resolution of the results. The results from these additional trials were included in the regression analysis performed by STRATEGY.

Table 1: S1licon wafer types included in surface texturing experinent. All wafers are 100-mm diameter and <100>-oriented.

\begin{tabular}{|c|c|c|c|c|}
\hline Suppl Ier & Type & & $\begin{array}{l}\text { 1stivity } \\
\text { ( } \Omega \mathrm{cm})\end{array}$ & Surfaces \\
\hline $\begin{array}{l}\text { Monsanto } \\
\text { Monsanto } \\
\text { Wacker } \\
\text { Unisil }\end{array}$ & $\begin{array}{l}\text { n-type, } \\
\text { p-type, } \\
\text { n-type, } \\
p \text {-type, }\end{array}$ & $\begin{array}{l}\mathrm{C}_{2} \\
\mathrm{C}_{2} \\
\mathrm{FZ} \\
\mathrm{MC}\end{array}$ & $\begin{array}{r}7-21 \\
14-25 \\
0.25 \\
0.30\end{array}$ & $\begin{array}{l}\text { Pollshed/Lapped } \\
\text { Pollshed/Lapped } \\
\text { Lapped/Lapped } \\
\text { Lapped/Lapped }\end{array}$ \\
\hline
\end{tabular}

Table 2: Process varlables (factors) and ranges used in surface texturing experiment.

\begin{tabular}{lcc} 
Factor & Lower Limit & Upper Limit \\
\hline Solution temperature ('C) & 70 & 90 \\
Time in solution (min) & 10 & 30 \\
Hechanical mixing & None & High \\
KOH concentration (B) & 1 & 5 \\
IPA concentration (t) & 1 & 20
\end{tabular}

\section{TEXTURING PROCESS DESCRIPTION}

The initial 18-trial experinent was conducted using - 4000-ml quartz vessel to contain the $\mathrm{KOH}$ solution. The quartz vessel and chemical solution were heated on a Corning hotplate, Hodel PC-351. equipped with a large $(5 \mathrm{~cm})$ magnetically-driven stirring bar. A flat, loose fltting, glass cover was used to cover the vessel during the etching process. The temperature of the solution was maintained within $\pm 2{ }^{\circ} C$ of the desired valia using this apparatus. The chenical solutions consisted primarlly of high-purity delonized vater ( $18 \mathrm{M} / \mathrm{cm})$. so the standard procedure Involved heating just the weter to a terperature near the desired level prlor ro adding KOH and IPA.

Note that the bolling point of IPA at sea-level is $82.5^{\circ} \mathrm{C}$; IPA should never be added to the solution $1 f$ the temperature is at or above this level. For additional anety, it is also prudent to add the IPA to the water prior to adding the $\mathrm{KOH}$. In case the water is hotter than anticipated, this avolds the possibility of spltting alkaline solution if the IPA bolls on contect.

Elght silicon wafers (two of each type) were used for each trial of the experiment. Wafers were held in adjacent slots in a Teflon wafer carrier (Fluoroware, Hodel A182-39M) when ubbersed in the $\mathrm{KOH}$ solution. The wafer carrier rested above the angnetlc stlr-bar on a $10 \mathrm{~cm}$ dianeter quartz ring about $2 \mathrm{cn}$ in helght. The range of mechanical axing varled froi none to the hlghest rotational rate that could be achleved without the stir-bar losing aagnetic coupling.

Prlor to each trial, and in order to provide a comon initial condition for each wafer type, new wafers were first etched for 60 seconds in buffered-oxide-etch (BOE). After the BOE, a surface-damage removal etch in a $1: 1$ olution of $\mathrm{KOH}: \mathrm{H} 2 \mathrm{O}$ at $85^{\circ} \mathrm{C}$ for 30 minutes was used to thin the wafers by epproxinately $30 \mathrm{~mm}$. The wafers were then stored in leopropyl elcohol for at least 10 anutes to prevent surface oxidation while valting for the texturing solution to reach the desired temperature. The wafers were then imersed in the texturing solution for the desired period of time, removed, and rinsed with delonized water.

Fresh solutions of ultrapure delonlzed water and semiconductor-grade $\mathrm{KOH}$ and IPA were mixed for each triel. The $\mathrm{KOH}$ was a 45 concentrated solution from General Chemical and the IPA was from the same supplier.

Subsequent to the Inltial 18-t-1al experinent conducted in the quartz vessel, additional textureetch trials were run in the PDFL using a commercial etch bath. The FilterChem etch bath, Model EDM4SHR, has a chemical capacity of about 20 liters and is equipped with chemical circulation pump (22 lpm) that f111s the etch tank from the bottom and cascades the solution over the top of the tank. The bath is made of Halar TH to be compatible with high temperature alkaline solutions. A alcroprocessor controlled heating system maintains the chemical solution within $\pm 0.5^{\circ} \mathrm{C}$ of the desired setpoint, but the system is linited to a maxinum temperature of approximately $80^{\circ} \mathrm{C}$. The bath is also equipped with a hinged cover that was closed after the wafer carrler was pleced in the etch cank. The cover was not alr-tlght and was opened at 5-min intervals in order to manually agitate the wafer carrier. Additional tests are planned to determine if this anual agitation is necessary.

After each trial, the wafers were rinsed and dried and number of easurements were performed on both eurfaces of each wafer. Wafer thickness was neasured before and after etching, NIKON optical alcrometer at $400 \mathrm{x}$ agnification vas used to measure typical pyranld base dimenstons. hemispherical spectral reflectance was measured with a Beckman spectzophotoneter, photographs were raken at $400 \mathrm{X}$ agnification, and in any cases a scanning electron microscope (SEM) was used to photograph the surface at $2000 \mathrm{X}$ agnification. 


\section{EXPERIMENTAL RESULTS}

The surface textures resulting from the different trials varied from no texture, to very large (30 $\mu$ base dimension) Individual pyramids that sparsely populated the surface, to a near ideal texture with uniform coverage of intermingled pyramids with base dimensivns from about 1 to $5 \mathrm{~mm}$. Figure 1

illustrates the case with large individual pyramids and Figure 2 IIlustrates the result of an effective surface terturing process. In general, pyramids with base dimensions larger than about $10 \mu m$ are undesirable from a cell fabrication standpoint. Such large pyramids can protrude through photoresist or interfere with other cell processing procedures.

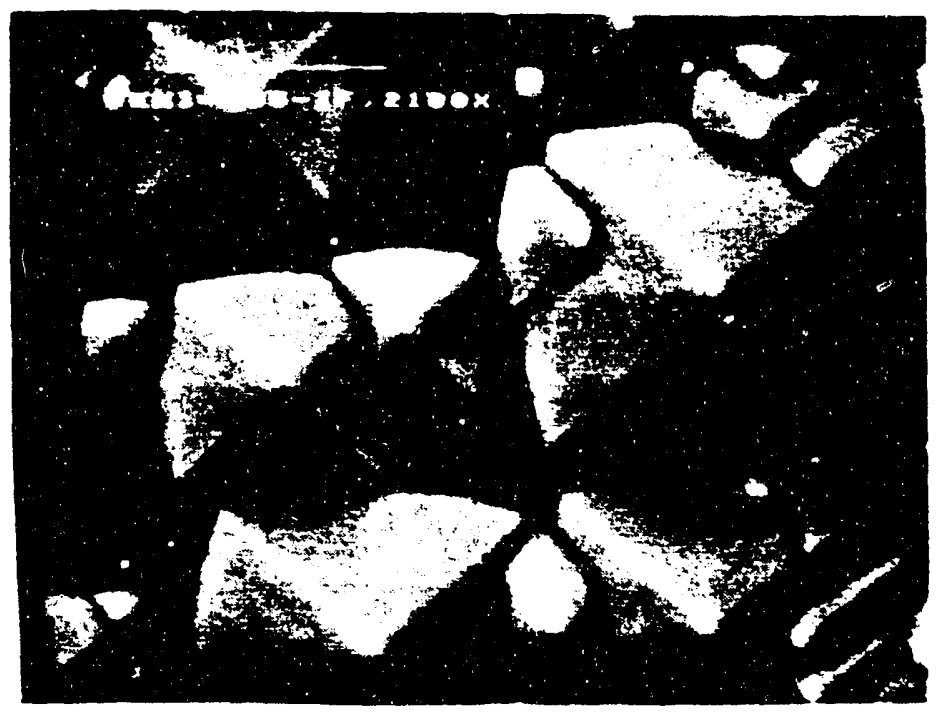

Figure 1: SEM photograph at 2100X aagnification for trial at $90^{\circ} \mathrm{C}$ for 30 minutes with $58 \mathrm{KOH}, 208$ IPA, and mechanical mixing.

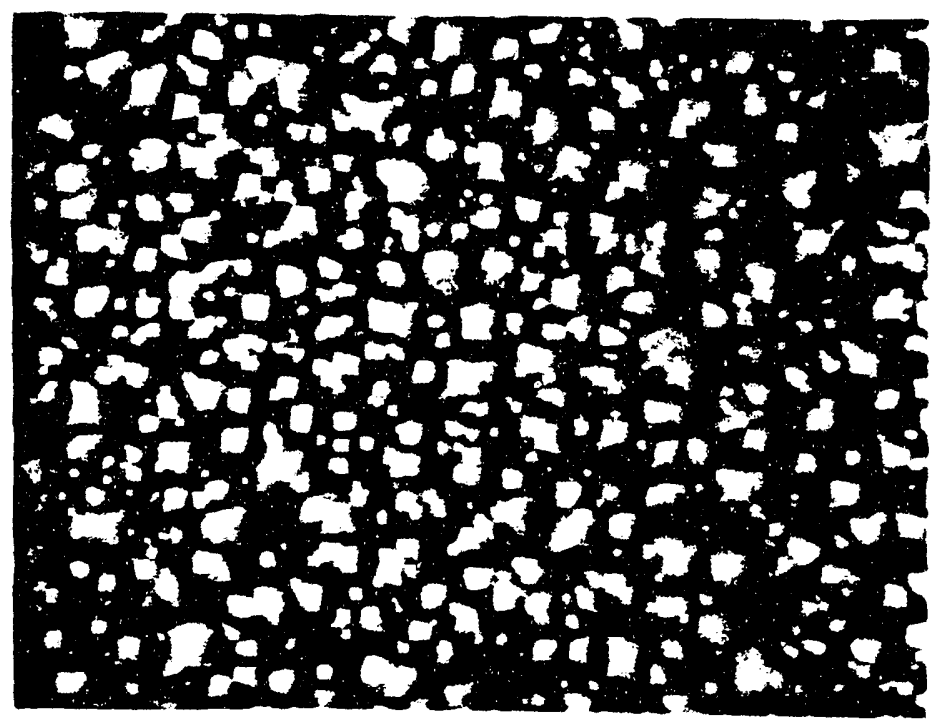

Figure 2: SEM photograph at 2200X magnification for trial at $70^{\circ} \mathrm{C}$ for 30 minutes with $1.58 \mathrm{KOH}, 3.8$ $I P A$, and mechanical mixing.
Figure 3 shows the hemlspherlcal spectral reflectance for an untextured wafer, and for a wafer with surface texture similar to that in Figure 2. Adjition of a 110-nm silicon dioxide antireflection coating resulted in the bottom curve shown in Figure 3, with less than 2 reflectance over most of the useful spectrum.

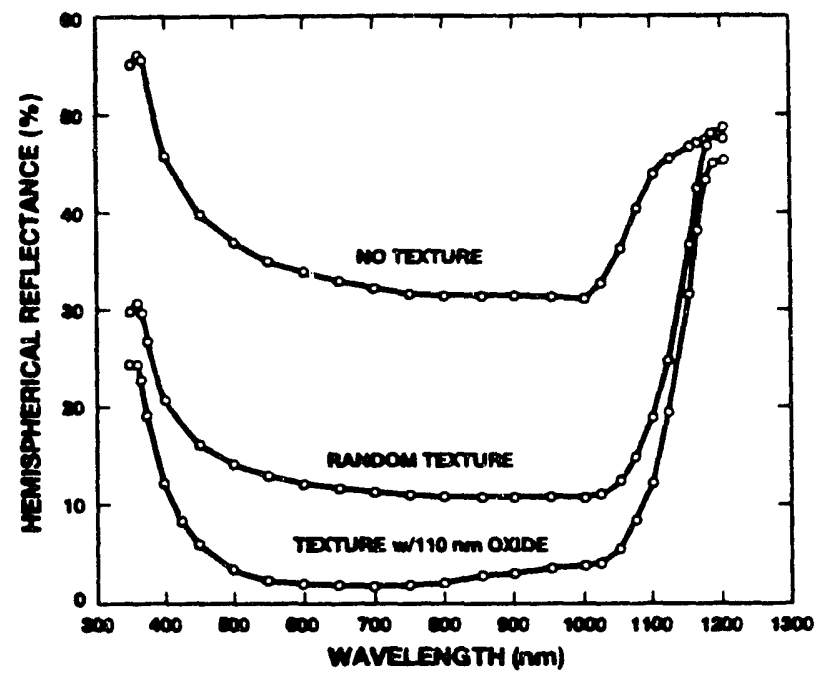

Figure 3: Hemispherlcal reflectance for silicon wafers with and without surface texture.

\section{MULTIFACTOR RESPONSE SURFACE}

Using the measured results from twenty trials conducted during the initial series of experiments in the quartz vessel and from an additional twelve trials in the commercial etch bath in the PDFL, the STRATEGY program was used to "fit" the results with respect to the flve process variables considered. A "five-factor interaction model" was used. allowing linear variation with each parameter as well as first order interactions between parameters. The hemispherical reflectance of the textured wafer at a 1000-nm wavelength was the measured response used for analysis. All reflectance measurements used in the regression analysis were made without antireflection coatings on the wafers.

Figures 4, 5, and 6 show selected "slices" through the 5-dimensional response surface associated with hemlspherical reflectance measurements on the ?and $n$-type wafers used. Our measurements indicated no significant difference between the $p$ - and $n$-type $\mathrm{Cz}$ wafers used, so the measured results were combined prior to regression analysis. The surface textures achleved on these $\mathrm{Cz}$ wafers were also independent of the Initial surface smoothness; the polished side of each wafer had a resulting texture and reflectance identical to the lapped side. As indicated by the contours in the figures, there was a high degree of interaction between the process variables considered; no single variable had a dominant affect on the quality of the surface texture. This high degree of interaction is consistent with the difficulty others have had in identifying a repeatable texturing process. 

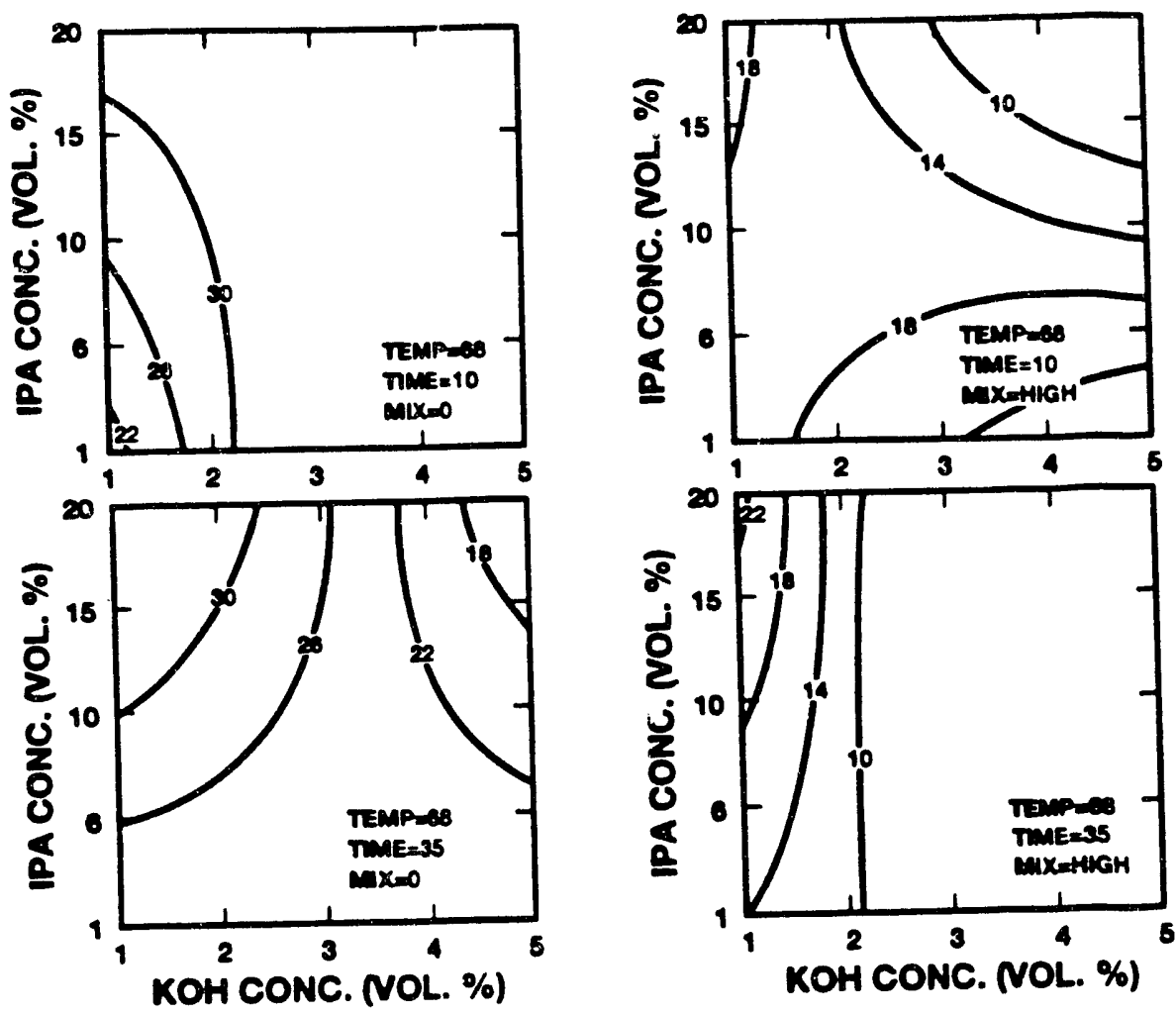

Figure 4: Results of regression fit to data from all texturing trials for $C z$ wafers for 4: 68 . Conto at $1000 \mathrm{~nm}$ solution temperature of 68 C. Contours $\mathrm{KOH}$ liquid solution. Time is in minutes.)
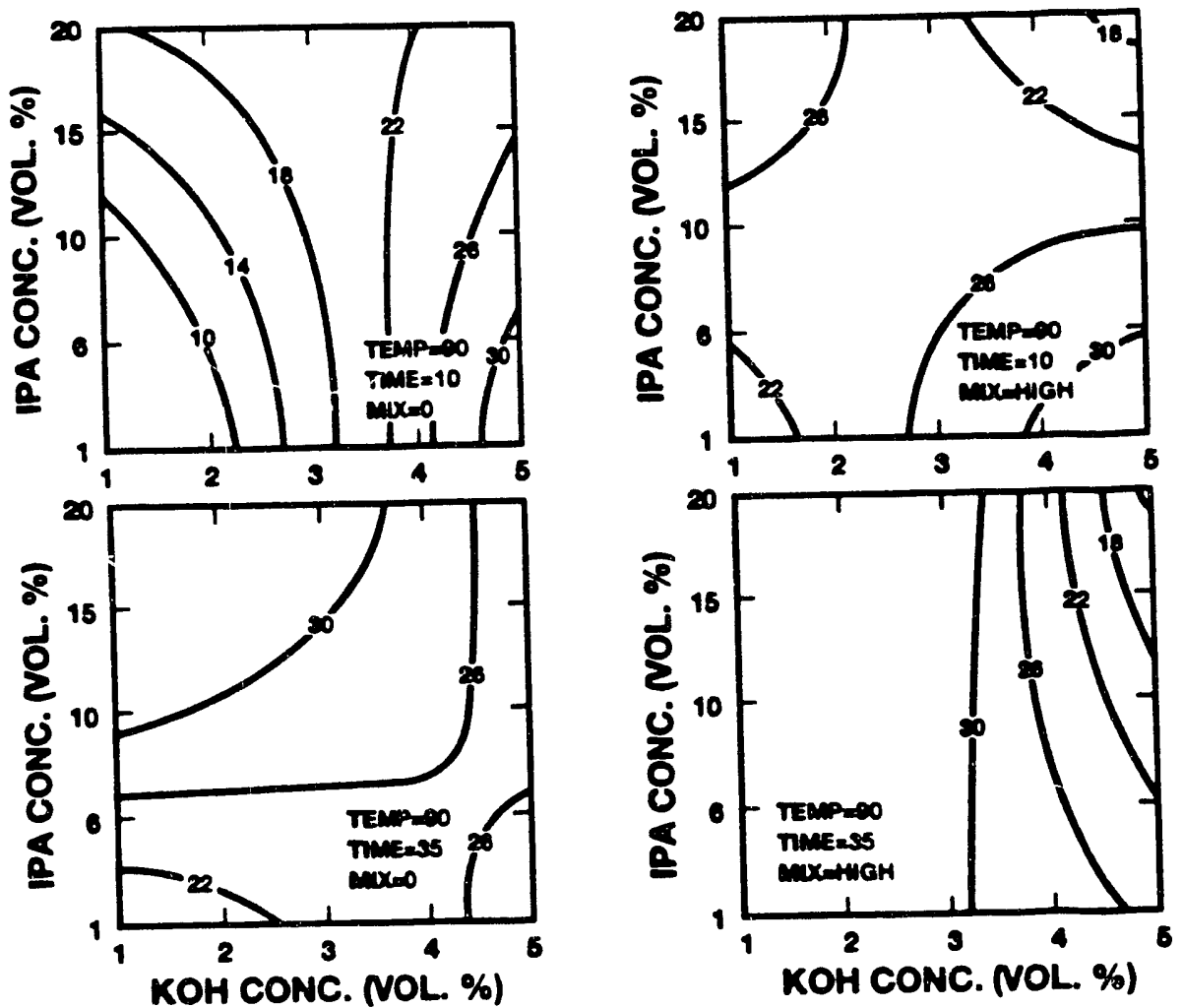

Figure 5: Resules of regression flt to data frow all texturing trials for Cz wafers for solution temperature of $90^{\circ} \mathrm{C}$. Contours are hemispherical reflectance ( at $1000 \mathrm{nr}$. 

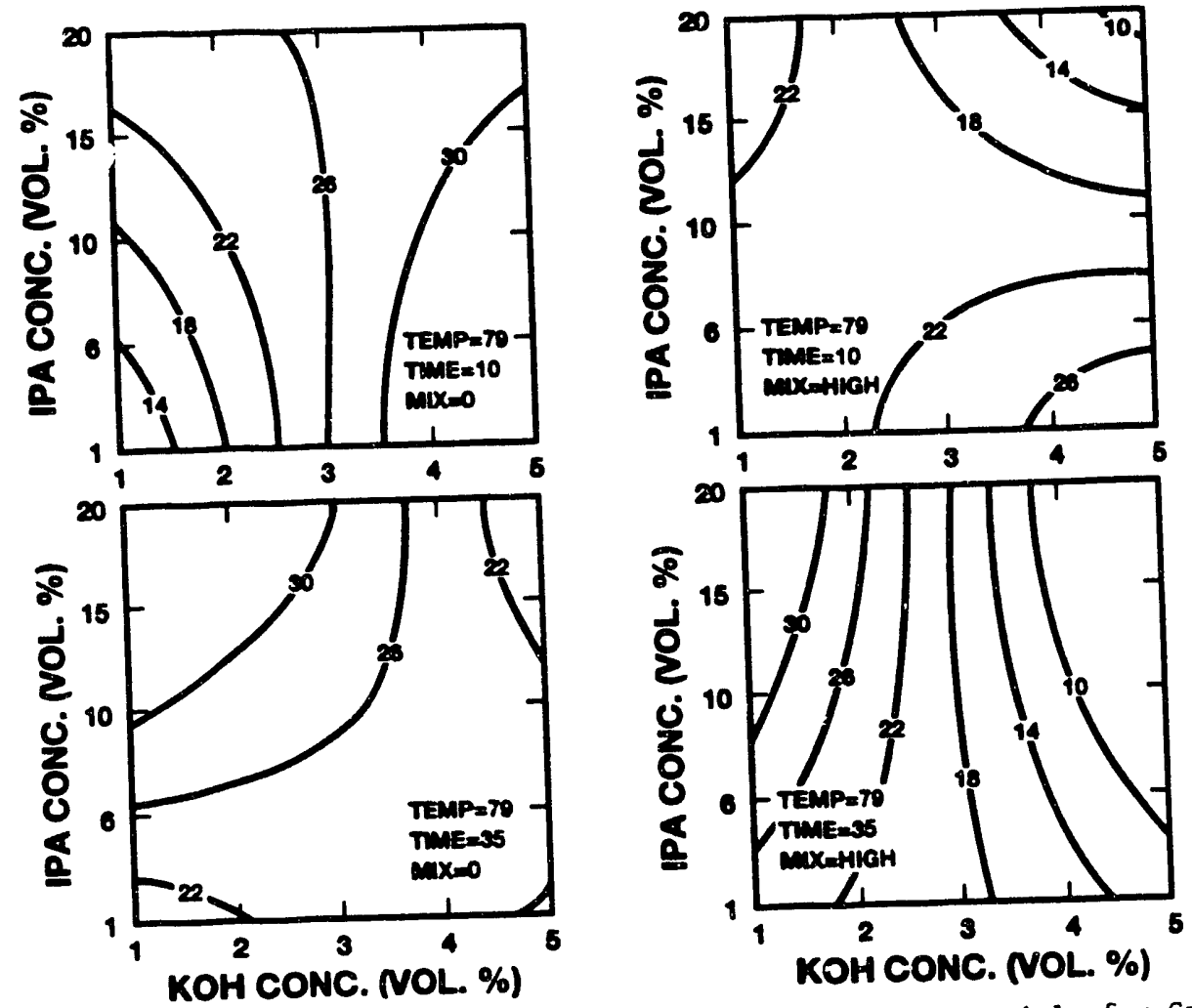

Figure 6: Results of regression fit to data from all texturing trials for Cz wafers for solution temperature of $79^{\circ} \mathrm{C}$. Contours are hemispherical reflectance $(8)$ at $1000 \mathrm{~nm}$.

The confidence limits associated with the contours The confidence limits assoclated wagnitude of each line residuals parameter. However, evaluation indicated that the contours fit the measured data within less than 58 contours fit for all but five of the thirty one trials conducted to date. As additional trials are trlals conducted corlable levels, the results will run at differente our resolution of the response surface. Nonetheless, the results now available sure reasonably clear indication of the process varlables that $g$ ive an effective surface texture.

Analysis of the reflectance measurements for $F 2$ and $\mathrm{MCz}$ wafers indicated a response surface similar to that for the $\mathrm{Cz}$ wafers. However, both $\mathrm{FZ}$ and $\mathrm{MCz}$ wafers had a slightly wider range of process varlables that resulted in an effective surface texture.

Other measured results such as silicon etch rates have not yet been thoroughly analyzed. However, the high temperature solutions with high $\mathrm{KOH}$ concentration clearly had the fastest etch rates, but typically did not result in the nost desirable surface textures.

\section{DISCUSSION}

Minimizing the reflection loss from the front surface of a solar cell is the primary motivation for surface texturing. However, several other things must be considered to ensure that the texturing process is compatible with other cell fabrication processes and is achlevable at an acceptable cost. As mentioned previously, pyramid diensions must be compatible with cell processing dimensions must be compatithography. In addition, chemical cost, vapor effluent during processing, chemical cost, vapor efluical solution can be reused, and chemical disposal cost are important considerations.

Perhaps the most important result from our work is the identification of an effective texturing process at reasonably low temperature $\left(70^{\circ} \mathrm{C}\right)$ and with low concentrations of both $\mathrm{KOH}$ and IPA. Although additional trials are required to fully confirm the results. Figure 4 indicates that with mechanical mixing at about $70^{\circ} \mathrm{C}$ a large range for mechanical mixing at about $\mathrm{KOH}$ and IPA concentration will result in an effective surface texture. Due to this broad range of acceptable KOH and IPA concentration, the contours in Figure 4 also suggest that it may be possible to reuse the texture solution several imes by starting with low concentrations of both chemicals and then replenishing the solution with fresh chemicals prior to each use. The relatively low temperature and low IPA concentration also significantly reduce the quantity of IPA vapor released to the atnosphere during processing. 
This low-temperature KOH solution also has a relatively slow etch-rate for silicon dioxide. making it possible to use an oxide mask to limit the texturing to selected areas, or to texture only one side of the wafer.

\section{CONCLUSION}

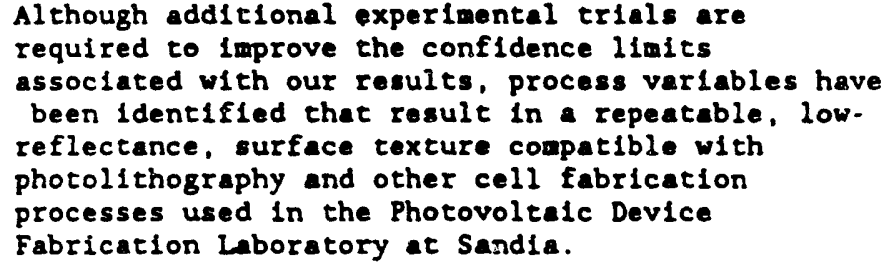

\section{ACKNOWLEDGEMENTS}

The authors would like to thank Beverly S1lva and Hisch Lehrer for aking a large number of reflectance measurements and optical and SEM micrographs. Thanks also to James Gee for intiating the use of our texture etching process in the commercial etch bath in the PDFL.

\section{REFERENCES}

[1] H. Seldel, et al., "Anlsotropic Etching of Crystalline S1licon in Alkaline Solutions," J. Electrochem. Soc., 137 (11), November 1990, Pp. $3612-3632$

12] M. Declercq, et al., "Optimization of the Hydrazine-Water Solution for Anisotropic Etching of Silicon," J. Electrochem. Soc., 122 (4), Apr11 1975, Pp. 545-552.

(3) P. Campbe11, et al., "Light Trapping and Reflection Control with Tileed Pyramids and Grooves," 20th IEEE PVSC, Sept. 1988, pp. 713. 716.

[4] G. Miner, "Development of a Polnt-Contact Solar Cell Using High-Volume Processing Techniques," Sandia Contractor Report, SAND897045 .

[5] A. Rohatg1, "Invest1gatica and Fabrication of High-Efficiency Silicon Solar Cells," Sandia Contractor Report, Contract No. 42-3377.

16] STRATEGY Version 4.91, Experiment Strategies Foundation, Seattle, WA.

\section{DISCLAIMER}

This report was prepared as an account of work sponsored by an agency of the United States Government. Neither the United States Government nor any agency thereof, nor any of their employees, makes any warranty, express or implied, or assumes any legal liability or responsibility for the accuracy, completeness, or usefulness of any information, apparatus, product, or process disclosed, or represents that its use would not infringe privatcly owned rights. Reference herein to any specific commercial product, process, or service by trade name, trademark, manufacturer, or otherwise does not necessarily constitute or imply its endorsement, recommendation, or favoring by the United States Government or any agency thereof. The views and opinions of authors expressed herein do not necessarily state or reflect those of the United States Government or any agency thereof. 

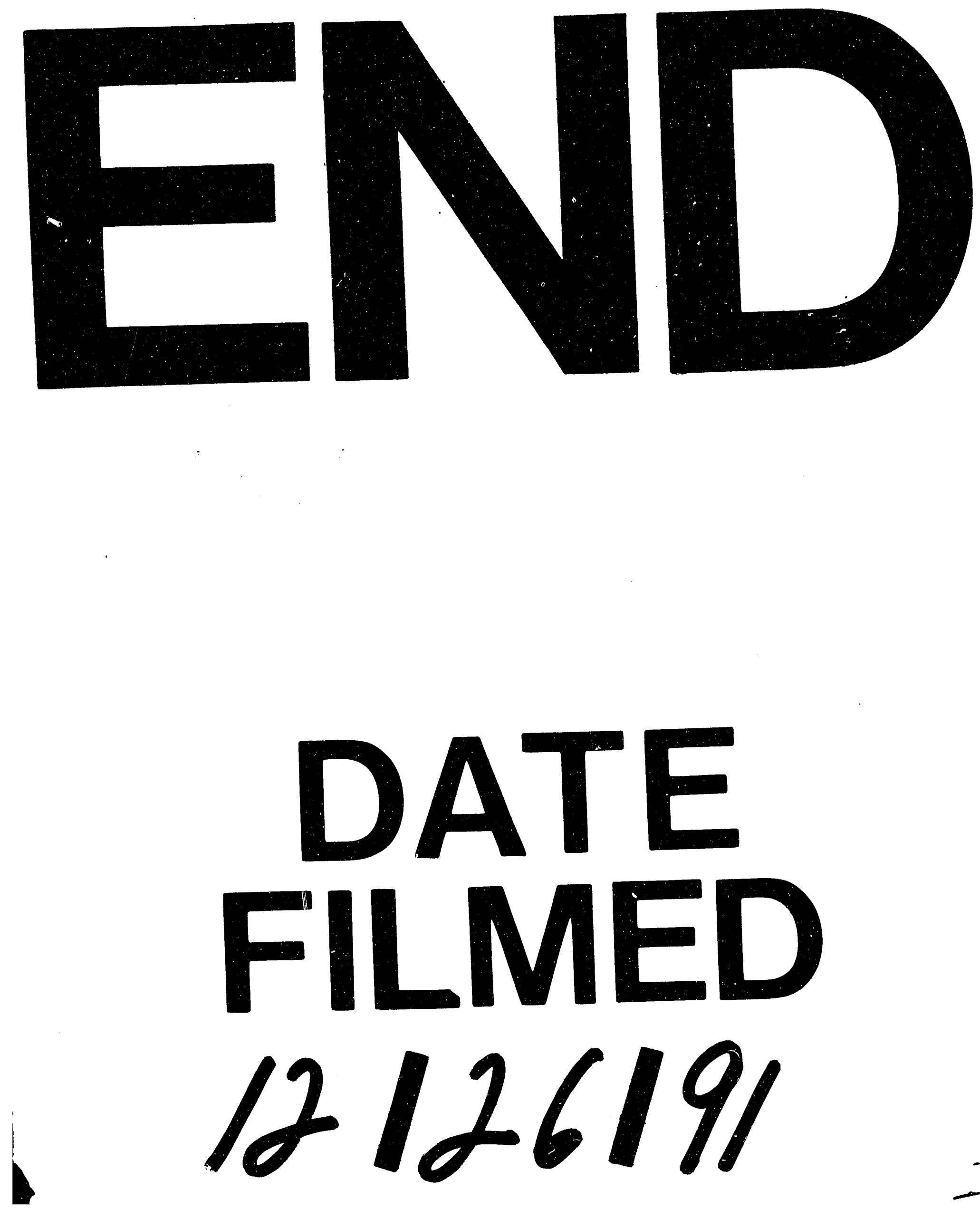

T 
